\title{
Oil Palm Empty Bunch Compost as a Source of Humic Acid
}

\section{*Irma Deva Oktavianti, Gusrizal \& Nurlina}

Kimia/MIPA - Universitas Tanjungpura, Pontianak - Indonesia 78124

Received 9 September 2020, Revised 13 October 2020, Accepted 13 November 2020 doi: 10.22487/j24775185.2020.v9.i4.pp205-212

\begin{abstract}
Humic acid is a fraction of humic compounds that are part of soil organic matter. In this research, humic acid is extracted from oil palm empty fruit bunches compost. Compost is made from the process of counting the empty oil palm bunches, which are composted until the compost is cooked. The humic acid extraction process uses a strong base extraction method. The principle of humic acid extraction is to dissolve the humic compound with a base solution and then separate it by adding an acid solution ( $\mathrm{HCl}$ solution). The extraction of humic acid from oil palm empty fruit bunches compost produced blackish-brown humic acid with a yield of $4.895 \%$. The result showed that the main functional group content of palm oil empty fruit bunches compost humic acid was the -OH group and phenol group which had a conjugated carbonyl group and a more aliphatic humic acid structure. Quantitatively, the functional groups of humic acid functional goups each amounted to a total acidity of 7,400 cmollkg, a carboxylic group of $520 \mathrm{cmol} / \mathrm{kg}$, and a phenolic -OH group content of $6,880 \mathrm{cmol} / \mathrm{kg}$. Research results show that oil palm empty fruit bunches compost can be used as a source of humic acid.
\end{abstract}

Keywords: Humic acid, extraction, compost

\section{Pendahuluan}

Asam humat merupakan salah satu fraksi dari senyawa humat yang merupakan bagian dari bahan organik tanah yang terbentuk secara alami. Senyawa humat berasal dari degradasi secara biologis (enzimatis), kimia maupun abiotik dari material organik yang ada di atas tanah. Secara fisik, asam humat berwarna kuning hingga coklat (Wershaw, 2004).

Penelitian mengenai peran asam humat dalam bidang pertanian dan kimia lingkungan telah banyak dilakukan. Menurut penelitian Wijaya dkk., (2013), asam humat berperan dalam memperbaiki akar tanaman sehingga tanaman tersebut dapat menyerap unsur hara yang lebih banyak. Selain memperbaiki akar tanaman, asam humat juga berperan dalam mengikat kation dari suatu logam, salah satunya adalah logam Zn(II) (Samat, 2013). Menurut Khaled \& Fawy (2011), pengaplikasian asam humat pada tanah berperan dalam meningkatkan penyerapan posforus $(\mathrm{P})$, kalium $(\mathrm{K})$, magnesium $(\mathrm{Mg})$, natrium $(\mathrm{Na})$, tembaga $(\mathrm{Cu})$ dan zink (Zn). Selain itu, asam humat juga dapat meningkatkan sifat fisik dan kimia tanah yang dapat membantu menghasilkan tanaman berkualitas tinggi dan terhindar dari erosi (Babarabie et al., 2016).

Asam humat dapat diisolasi dari gambut. Akan tetapi, gambut telah ditetapkan sebagai sumber daya alam yang dilindungi oleh Kementerian Lingkungan Hidup dan Kehutanan (KLHK). Hal ini karena peran ekosistem gambut dalam mempertahankan siklus hidrologi dan cadangan karbon bagi lingkungan hidup (Agus \& Subiksa, 2008). Sehingga eksplorasi gambut harus dibatasi. Eksplorasi asam humat dapat dilakukan dengan mencari sumber alternatif yang dapat dijadikan sumber asam humat.

Penelusuran sumber asam humat selain gambut dapat dimulai dari teori pembentukkan asam humat. Salah satu teori yang menjelaskan tentang pembentukkan asam humat ialah teori lignin. Menurut teori ini, asam humat terbentuk dari degradasi lignin oleh mikroorganisme (Stevenson, 1982). Berdasarkan teori tersebut, asam humat dapat diperoleh dari bahan yang kaya akan kandungan lignin. Lignin mengalami proses biologi dan kimia sehingga terdegradasi menjadi asam humat. Proses degradasi secara alami dapat ditiru secara sederhana melalui proses pengomposan. Pada umumnya, asam humat terbentuk dari proses dekomposisi bahan organik dengan jangka waktu

*Correspondence:

Nurlina

e-mail: nurlina@chemistry.untan.ac.id

(c) 2020 the Author(s) retain the copyright of this article. This article is published under the terms of the Creative Commons Attribution License 4.0, which permits unrestricted non-commercial use, distribution, and reproduction in any medium, provided the original work is properly cited. 
yang cukup lama yang dibantu oleh mikroorganisme pengurai. Hal ini serupa dengan teknik pengomposan, karena teknik pengomposan merupakan salah satu cara dekomposisi bahan organik.

Kompos dapat berasal dari limbah padat organik. Tandan kosong sawit merupakan salah satu limbah padat organik yang dapat dijadikan sebagai kompos. Tandan kosong sawit memiliki komposisi utama selulosa $37 \%$ dan lignin sebanyak 16,49\% (Hambali dkk., 2007). Pembuatan kompos tandan kosong sawit dapat dilakukan dengan menambahkan bioaktivator atau tanpa penambahan bioaktivator. Limbah padat organik seperti tandan kosong sawit jika diolah dengan teknik pengomposan yang ditambahkan dengan bioaktivator dapat menghasilkan asam humat (Isroi dkk., 2000). Pada tulisan ini akan dijelaskan isolasi dan karakterisasi asam humat dari kompos tandan kosong sawit. Kompos dibuat melalui proses pengomposan tanpa penambahan bioaktivator.

\section{Metode}

Alat yang digunakan meliputi alat gelas, pH-meter, shaker, sentrifugator, FTIR (Perklin Elmer Frontier Optica), perangkat UV-Vis (Shimadzu UV 1280), dan timbangan analitik. Bahan yang digunakan adalah akuades, asam klorida, barium hidroksida, barium asetat, kompos tandan kosong sawit, larutan perak nitrat, natrium hidroksida, natrium bikarbonat, dan plastik selofan.

Pembuatan Kompos Tandan Kosong Sawit (TKS)

Tandan kosong sawit (TKS) diperoleh dari salah satu perkebunan sawit yang ada di Kabupaten Mempawah Provinsi Kalimantan Barat. Tandan kosong sawit yang diperoleh yaitu dalam keadaan basah. Tandan kosong sawit selanjutnya dihaluskan menggunakan mesin pencacah dengan tujuan untuk memperkecil ukuran tandan kosong sawit. Tandan kosong sawit yang telah halus diharapkan dapat mempercepat dekomposisi TKS. Tandan kosong sawit yang sudah halus selanjutnya dimasukkan ke dalam karung dan ditutup selama beberapa waktu sampai bahan tersebut menjadi kompos. Temperatur kompos dipertahankan pada temperatur $25-40{ }^{\circ} \mathrm{C}$. Jika temperatur lebih dari 40 ${ }^{\circ} \mathrm{C}$ maka tutup karung harus dibuka dan adonan kompos harus dibolak balik. Kompos yang telah terbentuk memiliki ciri fisik bewarna kehitaman, tidak berbau dan temperatur kompos konstan ( \pm melebihi $50^{\circ} \mathrm{C}$ ) (Warsito dkk., 2016).

\section{Isolasi Asam Humat Dari Kompos Tandan Kosong Sawit}

Kompos tandan kosong sawit yang telah terbentuk disaring terlebih dahulu untuk menghilangkan sisa-sisa kotoran tandan kosong sawit. Kompos ditimbang 50 gram, ditambahkan $500 \mathrm{~mL} \mathrm{NaOH}$ 0,1 M. Campuran tersebut dikocok selama kurang lebih 2 jam dan kemudian didiamkan selama 24 jam. Setelah didiamkan, campuran disaring. Hasil filtrat diambil untuk disaring kembali menggunakan pompa vakum. Filtrat hasil saringan diasamkan dengan $\mathrm{HCl} 6 \mathrm{M}$ sampai mencapai $\mathrm{pH}$ 1. Filtrat dikocok dengan shaker selama kurang lebih 2 jam, selanjutnya didiamkan selama 24 jam. Filtrat yang sudah didiamkan selama 24 jam kemudian disentrifugasi dengan kecepatan 3500 rpm selama 15 menit untuk menghasilkan endapan (Stevenson, 1994).

Endapan yang dihasilkan dari sentrifugasi dilarutkan kembali dengan $\mathrm{NaOH} \mathrm{0,3} \mathrm{M.} \mathrm{Larutan}$ disentrifugasi dengan kecepatan 3500 rpm selama 15 menit dan kemudian larutan disaring kembali. Filtrat hasil penyaringan diasamkan dengan $\mathrm{HCl} 6$ M sampai pH 1, kemudian dikocok selama 2 jam dengan shaker. Campuran tersebut didiamkan selama 24 jam. Setelah 24 jam, campuran disentrifugasi dengan kecepatan 3500 rpm selama 15 menit. Hasil sentrifugasi akan diperoleh endapan dan filtrat.

Endapan hasil sentrifugasi dimasukkan ke dalam plastik selofan dan didialisis dalam air selama beberapa hari untuk menghilangkan garam $\mathrm{AgCl}$. Air hasil rendaman diuji dengan menambahkan larutan $\mathrm{AgNO}_{3}$ untuk melihat kandungan garam dalam air rendaman. Apabila sudah tidak terbentuk endapan putih $(\mathrm{AgCl})$ menunjukkan uji negatif keberadaan garam di dalam asam humat. Endapan asam humat yang dihasilkan dari proses dialisis kemudian dikeringkan di dalam oven pada temperatur $60{ }^{\circ} \mathrm{C}$ selama kurang lebih 2 jam (Stevenson, 1994).

\section{Karakterisasi Asam Humat Hasil Isolasi Dengan FTIR}

Asam humat yang diperoleh dari proses isolasi kompos tandan kosong sawit dianalisis dengan spektrofotometer FT-IR untuk mengetahui gugus fungsi yang terdapat di dalam asam humat. Adapun metode yang digunakan dalam penyiapan sampel untuk analisis asam humat dengan instrumen ini adalah menggunakan pellet $\mathrm{KBr}$.

\section{Penentuan Rasio $E_{4} / E_{6}$ Asam Humat}

$2 \mathrm{mg}$ asam humat dilarutkan dalam $10 \mathrm{~mL}$ larutan $\mathrm{NaHCO}_{3}$ 0,05 N. Sampel larutan diukur menggunakan spektrofotometer UV-Vis pada panjang gelombang 200-800 dan dilihat berapa absorbansinya (Stevenson, 1994).

\section{Penentuan Spektra Diferensial UV-Vis Asam Humat}

$15 \mathrm{mg}$ asam humat dilarutkan dalam 100 mL larutan $\mathrm{NaOH} 0,05 \mathrm{~N}$. Larutan tersebut diambil masing-masing $10 \mathrm{~mL}$ dari larutan awal dan ditambahkan akuades $40 \mathrm{~mL}$. Masing-masing larutan diatur $\mathrm{pH}$-nya menjadi $\mathrm{pH} 7$ dan $\mathrm{pH} 12$ dengan larutan $\mathrm{HCl}$ dan $\mathrm{NaOH}$. Kedua larutan asam humat tersebut diukur absorbansinya pada panjang gelombang 300- $800 \mathrm{~nm}$ (Gusriza \& Afgani, 2005).

\section{Penetapan Keasaman Total Asam Humat}

$50 \mathrm{mg}$ asam humat dimasukkan ke dalam labu takar $100 \mathrm{~mL}$ dan ditambahkan $20 \mathrm{~mL}$ larutan 
$0,1 \mathrm{M} \mathrm{Ba}(\mathrm{OH})_{2}$. Labu takar ditutup rapat dan dikocok selama 24 jam. Suspensi yang terbentuk disaring dan residunya dibilas dengan air destilat bebas $\mathrm{CO}_{2}$. Filtrat dan air bilasan kemudian digabung dan selanjutnya dititrasi secara potensiometri dengan larutan standar $\mathrm{HCl} 0,5 \mathrm{M}$ sampai $\mathrm{pH}$ menjadi 8,4. Prosedur yang sama dilakukan untuk larutan blanko yang hanya mengandung $20 \mathrm{~mL} \mathrm{Ba}(\mathrm{OH})_{2}$ 0,1 M. Keasaman total dihitung dengan persamaan (Stevenson, 1994):

$\mathrm{KT}=\frac{\mathrm{Vb}-\mathrm{Vs} \times \mathrm{N} \times 10^{6}}{\mathrm{mg} \mathrm{sampel}} \mathrm{cmol} / \mathrm{kg}$

dimana $\mathrm{N}$ adalah normalitas larutan; $\mathrm{Vs}$ adalah volume sampel $(\mathrm{mL})$; dan $\mathrm{Vb}$ adalah volume blanko $(\mathrm{mL})$.

\section{Penentuan Gugus Karboksil (-COOH)}

$50 \mathrm{mg}$ asam humat dimasukkan ke dalam erlenmeyer dan ditambahkan $10 \mathrm{~mL}$ larutan $\mathrm{Ba}\left(\mathrm{CH}_{3} \mathrm{COOH}\right)$ 0,2 $\mathrm{M}$ dan $40 \mathrm{~mL}$ aquades. Dalam waktu yang sama dilakukan pula terhadap larutan blanko yaitu $10 \mathrm{~mL}$ larutan $\mathrm{Ba}\left(\mathrm{CH}_{3} \mathrm{COOH}\right) 0,2 \mathrm{M}$ dan $40 \mathrm{~mL}$ aquades kemudian larutan dikocok menggunakan shaker selama 24 jam pada temperatur ruang. Suspensi yang terbentuk disaring kemudian residu dibilas dengan aquades. Filtrat dan air bilasan digabung kemudian dititrasi dengan menggunakan larutan standar $0,1 \mathrm{M} \mathrm{NaOH}$ hingga ph 9,8. Adapun total keasaman humat dapat dihitung dengan menggunakan persamaan (Stevenson, 1994):

$[-\mathrm{COOH}]=\frac{\mathrm{Vs}-\mathrm{Vb} \times \mathrm{N} \times 10^{6}}{\mathrm{mg} \mathrm{sampel}} \mathrm{cmol} / \mathrm{kg}$

dimana $\mathrm{N}$ adalah normalitas $\mathrm{NaOH} ; \mathrm{Vb}$ adalah volume $\mathrm{NaOH}$ blanko $(\mathrm{mL})$; dan $\mathrm{Vs}$ adalah volume $\mathrm{NaOH}$ sampel (mL).

\section{Penentuan (-OH) Fenolik}

Kandungan gugus $-\mathrm{OH}$ fenolat merupakan selisih antara keasaman total dengan kandungan gugus $-\mathrm{COOH}$. Perhitungan kandungan gugus $-\mathrm{OH}$ fenolat dalam $\mathrm{cmol} / \mathrm{kg}$ dilakukan dengan persamaan (Stevenson, 1994): $[-\mathrm{OH}]$ fenol $=[$ keasaman total $]-[-\mathrm{COOH}]$.

\section{Hasil dan Pembahasan}

Proses pengomposan menghasilkan kompos yang sudah matang sebanyak $8,8 \mathrm{~kg}$ dari 20 $\mathrm{kg}$ tandan kosong sawit. Kompos yang sudah matang bewarna coklat kehitaman dengan temperatur yang sudah konstan, teksturnya hancur dan rasio $\mathrm{C} / \mathrm{N}$ 17,72. Penentuan rasio $\mathrm{C} / \mathrm{N}$ bertujuan untuk melihat tingkat kematangan kompos yang berdasarkan pada jumlah karbon total dan nitrogen total. Rasio C/N merupakan indikator kualitas dan tingkat kematangan dari bahan kompos (Sutanto, 2002).

Hasil penelitian nilai rasio $\mathrm{C} / \mathrm{N}$ kompos tandan kosong sawit sebesar 17,72 dengan nilai $\mathrm{C}$ organik sebesar $42,34 \%$ dan nilai $\mathrm{N}$ total sebesar 2,39 \%. Menurut SNI 19-7030-2004 standar rasio $\mathrm{C} / \mathrm{N}$ adalah 10-20 yang dianggap sebagai nilai kemataangan kompos yang berlaku di Indonesia. Hal ini menunjukkan bahwa hasil penelitiaan memenuhi kriteria SNI.

\section{Pemisahan dan Pemurnian Asam Humat dari Kompos Tandan Kosong Sawit}

Asam humat pada penelitian ini diekstraksi dari kompos tandan kosong sawit. Proses ekstraksi asam humat menggunakan metode ekstraksi basa kuat. Prinsip ekstraksi asam humat adalah melarutkan senyawa humat dengan larutan basa (larutan $\mathrm{NaOH}$ ) dan memisahkannya atau mengendapkannya dengan menambahkan larutan asam (larutan $\mathrm{HCl}$ ) (Stevenson, 1994). Ekstraksi asam humat dari kompos tandan kosong sawit menghasilkan asam humat yang bewarna coklat kehitaman dengan randemen sebesar 4,8 \%.

Proses pemisahan asam humat dimulai dari ekstraksi menggunakan basa kuat. Asam humat larut dalam larutan basa, sehingga warna larutan menjadi hitam pekat. Hal ini sesuai dengan hasil penelitian Gaffney dkk. (1996), yang menunjukkan bahwa asam humat dan fulvat larut di dalam larutan natrium hidroksida. Larutan kompos diasamkan dengan $\mathrm{HCl}$ pekat sampai dengan $\mathrm{pH} 1$. Penggunaan $\mathrm{HCl}$ bertujuan untuk mengendapkan asam humat. Hal ini karena sifat asam humat yang dapat larut dalam basa tetapi tidak larut di dalam asam atau air. Larutan yang sudah diasamkan kemudian disentrifugasi, sehingga didapatkan dua lapisan yaitu lapisan atas dan lapisan bawah, dimana lapisan atas (supernatan) yang diduga merupakan asam fulvat yang dicirikan dengan larutannya bewarna kuning dan lapisan bawah (endapan) adalah asam humat yang mana endapannya bewarna coklat kehitaman.

\section{Spektra FTIR Asam Humat}

Karakterisasi asam humat hasil isolasi menggunakan FTIR menghasilkan spektrum yang ditunjukkan pada Gambar 1. Interpretasi gugus fungsinya dapat dilihat pada Tabel 1 . 
Tabel 1. Interpretasi dari spektra FTIR asam humat hasil ekstraksi

\begin{tabular}{|c|c|c|}
\hline \multicolumn{2}{|c|}{ Bilangan gelombang } & \multirow[b]{2}{*}{ Gugus yang terkait } \\
\hline $\begin{array}{l}\text { Asam humat } \\
\text { hasil isolasi }\end{array}$ & Asam humat & \\
\hline 3366,00 & $3400-3300^{a}$ & Vibrasi ulur gugus $-\mathrm{OH}, \mathrm{N}-\mathrm{H}$ \\
\hline 2945,72 & $2940-2900^{a}$ & Regang C-H alifatik \\
\hline 1628,25 & $1650-1615^{b}$ & $\begin{array}{l}\text { Regang } \mathrm{C}=\mathrm{O} \text { (amida } \mathrm{I} \text { ), } \mathrm{C}=\mathrm{C} \text { aromatik dan ikatan hidrogen } \mathrm{C}=\mathrm{O} \text {, ikatan } \\
\text { rangkap terkonjugasi dengan getaran karbomil dan } \mathrm{COO}^{-}\end{array}$ \\
\hline 1445,83 & $1400-1390^{\mathrm{a}}$ & Deformasi O-H, ulur $\mathrm{CH}_{3}$ \\
\hline 1235,04 & $1280-1230^{\mathrm{a}, \mathrm{b}}$ & $\begin{array}{l}\text { Vibrasi ulur regang } \mathrm{C}-\mathrm{O} \text {, aromatik } \mathrm{C}-\mathrm{O} \text {, } \mathrm{CO} \text { ester, }-\mathrm{OH} \text { fenolik dan } \\
\text { deformasi } \mathrm{OH} \text { dari } \mathrm{COOH}\end{array}$ \\
\hline
\end{tabular}

Keterangan : a. Stevenson b. Tan

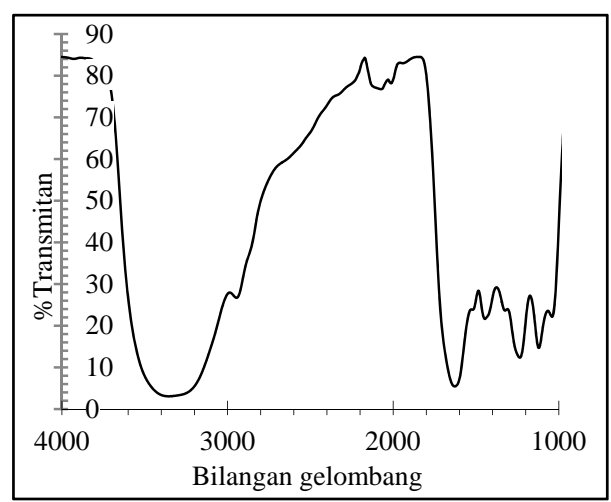

Gambar 1. Spektrum FTIR asam humat hasil ekstraksi.

Berdasarkan Gambar 1. terdapat pita absorpsi pada bilangan gelombang $3366,0 \mathrm{~cm}^{-1}$ yang merupakan vibrasi ulur gugus -OH. Pita absorpsi pada bilangan gelombang $2945,72 \mathrm{~cm}^{-1}$ merupakan regang $\mathrm{C}-\mathrm{H}$ alifatik. Sedangkan pita absorpsi didaerah sekitar bilangan gelombang $1720 \mathrm{~cm}^{-1}$ yang mana menunjukkan vibrasi ulur $\mathrm{C}=\mathrm{O}$ dari gugus $-\mathrm{COOH}$ pada penelitiaan ini tidak muncul, hal ini disebabkan adanya gangguan ikatan hidrogen dari senyawa asam humat (Narsito, dkk., 2008). Gangguan ini dapat diperkuat jika dilihat dari bentuk pita adsorpsi yang melebar pada daerah bilangan gelomabang $3366,0 \mathrm{~cm}^{-1}$ yang mana menunjukkan adanya pengaruh ikatan hidrogen pada senyawa humat (Rahmawati, 2011). Pita absorpsi pada bilangan gelombang $1628,25 \mathrm{~cm}^{-1}$ diinterpretasikan sebagai regang $\mathrm{C}=\mathrm{O}$ (amida $\mathrm{I}$ ), $\mathrm{C}=\mathrm{C}$ aromatik, ikatan hidrogen $\mathrm{C}=\mathrm{O}$ dan ikatan rangkap terkonjugasi dengan getaran karbomil dan $\mathrm{COO}^{-}$, hal ini diperkuat dengan munculnya pita absorpsi lemah pada bilangan gelombang 1515, 23 $\mathrm{cm}^{-1}$. Selain itu, didapatkan juga pita absorpsi pada daerah bilangan $1445,83 \mathrm{~cm}^{-1}$ yang mana menunjukan adanya deformasi O-H. Vibrasi ulur regang $\mathrm{C}-\mathrm{O}$, aromatik $\mathrm{C}-\mathrm{O}$, $-\mathrm{OH}$ fenolik dan deformasi $\mathrm{O}-\mathrm{H}$ dari $-\mathrm{COOH}$ diperkuat dengan munculnya pita absorpsi pada daerah bilangan gelombang 1235,04 $\mathrm{cm}^{-1}$.

Berdasarkan interpretasi spektra Gambar 1 menunjukkan bahwa spektra yang dihasilkan mencirikan spektra asam humat. Hal ini karena gugus- gugus fungsi yang dihasilkan menunjukkan ciri khas asam humat yang memiliki gugus $-\mathrm{OH}$, regang $\mathrm{C}=\mathrm{O}$, regang $\mathrm{C}-\mathrm{O}$, $-\mathrm{OH}$ fenolik, dan deformasi $-\mathrm{OH}$ dari $-\mathrm{COOH}$.

\section{Spektra ultraungu/ sinar tampak asam humat}

Spektrum UV- Vis asam humat hasil ektraksi tidak menunjukkan adanya suatu puncak maksimum dan minimum yang jelas, akan tetapi memiliki absorbansi tertinggi didaerah UV, yang mana disertai dengan absorbansi yang menurun dengan bertambahnya panjang gelombang. Hasil penelitiaan ini memiliki kemiripan dengan penelitiaan Stevenson (1994), yang mana karakteristik serapan asam humat pada panjang gelombang 200- $400 \mathrm{~nm}$ (ultraviolet).

Karakterisasi asam humat dengan spektrofotometer UV-Vis menghasilkan spektrum yang ditunjukkan pada Gambar 2. Spektrum UVVis asam humat hasil ekstraksi menunjukkan adanya absorpsi pada daerah ultra ungu dan sinar tampak yang mana disebabkan dengan adanya 
transisi elektron pada orbital $\sigma, \mathrm{n}$, dan $\pi$ ke orbital yang memiliki tingkat energi yang lebih tinggi. Selain itu absorpsi juga terjadi akibat perpindahan elektron dari suatu kromofor ke kromofor lain (Senesi \& Loffredo, 1998).

Karakteristik asam humat dapat dilakukan dengan mengetahui rasio $\mathrm{E}_{4} / \mathrm{E}_{6}$ dari asam humat. Rasio tersebut merupakan perbandingan nilai absorbansi pada panjang gelombang 465 dan 665 $\mathrm{nm}$. Rasio $\mathrm{E}_{4} / \mathrm{E}_{6}$ digunakan untuk mengetahui tingkat aromatik dari suatu senyawa humat. Menurut penelitian Stevenson (1994), rasio $\mathrm{E}_{4} / \mathrm{E}_{6}$ asam humat adalah kurang dari 5, sedangkan untuk asam fulvat adalah 6-8,5. Nilai rasio $\mathrm{E}_{4} / \mathrm{E}_{6}$ tidak mutlak, hal ini karena tergantung dari bahan utama yang digunakan untuk menghasilkan asam humat. Berdasarkan spektrum pada Gambar 2. diperoleh nilai $\mathrm{E}_{4} / \mathrm{E}_{6}$ hasil penelitian sebesar 6.21. Hasil penelitian ini menunjukkan hasil yang serupa dengan penelitian Basuki, dkk., (2017), dimana nilai rasio $\mathrm{E}_{4} / \mathrm{E}_{6}$ asam humat yang dihasilkan sebesar 6,275. Hal ini karena rasio yang rendah dapat menunjukkan tingkat konstituen aromatik yang relatif tinggi, sedangkan rasio tinggi menunjukkan adanya struktur yang relatif lebih alifatik. Berdasarkan hasil penelitiaan ini, dapat dikatakan bahwa nilai rasio $\mathrm{E}_{4} / \mathrm{E}_{6}$ pada penelitiaan ini menunjukkan adanya struktur asam humat yang relatif lebih alifatik dengan gugus fungsi yang lebih banyak, hal ini karena rasio $\mathrm{E}_{4} / \mathrm{E}_{6}$ yang dihasilkan tinggi.

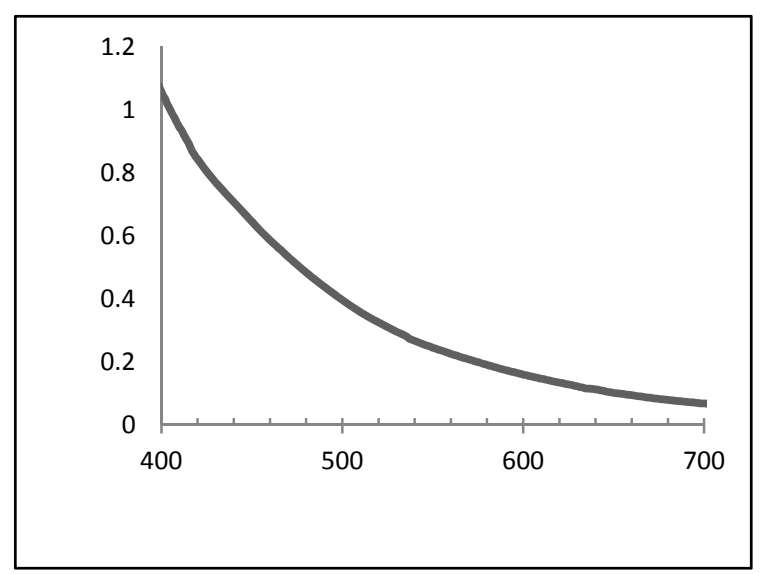

Gambar 2. Spektrum rasio $\mathrm{E}_{4} / \mathrm{E}_{6}$ asam humat

Pada saat analisis asam humat menggunakan spektrofotometer UV-Vis, adsorpsi UV-Vis oleh asam humat dapat dipengaruhi oleh $\mathrm{pH}$ larutan. Hal ini karena berubahnya warna pada larutan asam humat, dimana semakin basa $\mathrm{pH}$ larutan maka warna larutan semakin pekat. Perubahan warna tersebut diakibatkan adanya perubahan struktur zat humat yang disebabkan oleh disosiasi gugus karboksil dan fenolat (Tsutsuki And Kuwatsuka, 1979). Perubahan struktur zat humat mempengaruhi spektrum asam humat, dimana pada

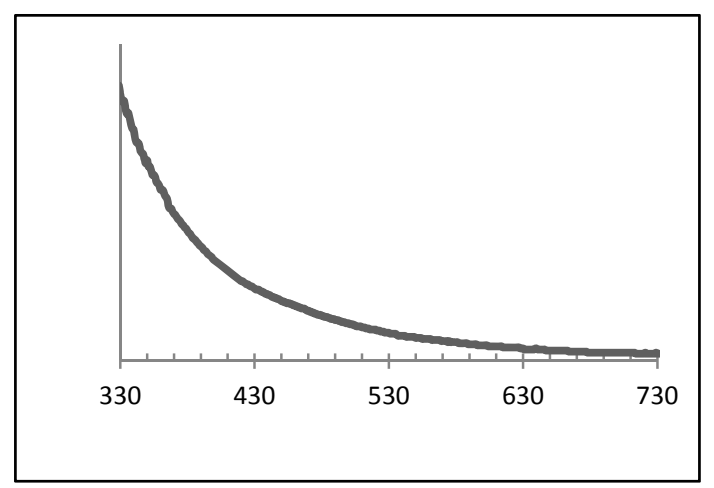

Gambar 3. Spektrum asam humat $\mathrm{pH}=7$. pengukuran spektrum asam humat menggunakan pH 7 dan pH 12 larutan asam humat menghasilkan spektrum dengan intensitas yang berbeda yang dapat dilihat pada Gambar 3. dan Gambar 4. Berdasarkan spektrum Gambar 3. dan Gambar 4, pola spektrum yang dihasilkan tidak berubah, akan tetapi terdapat perubahan intensitas. Bila kedua spektrum ini digabung, maka akan didapatkan selisih antara spektrum $\mathrm{pH} 7$ dan $\mathrm{pH} 12$ yang disebut differential spektra.

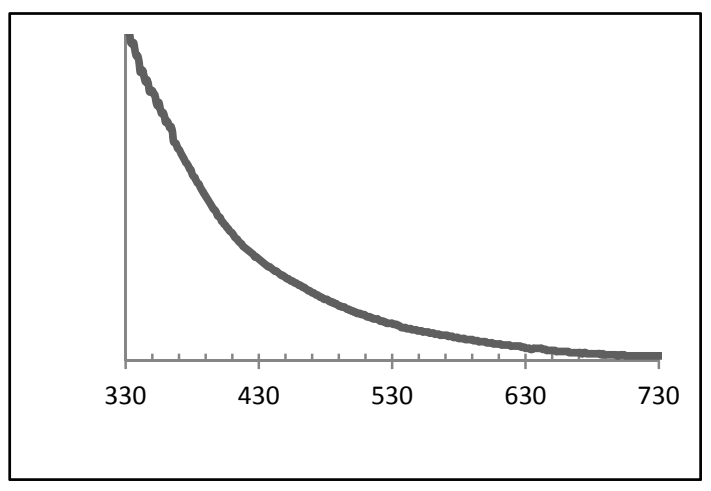

Gambar 4. Spektrum asam humat $\mathrm{pH}=12$ 
Asam humat mempunyai sejumlah kromofor dengan pita absorpsi yang tumpang tindih. Hal ini menyatakan bahwa spektrum Uv-Vis hanya dapat memberikan informasi yang terbatas untuk menyatakan gugus kromofor yang terdapat pada suatu asam humat. Berdasarkan absorpsi oleh asam humat yang dapat dipengaruhi oleh $\mathrm{pH}$ larutan maka karakterisasi asam humat dapat dilakukan dengan cara ionization difference spectra yang mana merupakan selisish spektrum larutan asam humat pada $\mathrm{pH}=12$ dan $\mathrm{pH}=7 \quad\left(\Delta \mathrm{E}_{7-12}\right)$.
Adapun spektrum $\Delta \mathrm{E}_{7-12}$ hasil penelitian dapat dilihat pada Gambar 5. Pita serapan pada spektrum $\Delta \mathrm{E}_{7-12}$ disebabkan oleh ionisasi gugus hidroksil fenolik dalam larutan basa. Jika ionisasi gugus hidroksil fenolik terikat dengan proton di dalam larutan netral yang meningkat dengan meningkatnya $\mathrm{pH}$, maka kenaikan tingkat eletron $\pi$ dan pita absorpsi bergeser kepanjang gelombang yang lebih panjang (Watanabe \& Kuwatsuka, 1991).

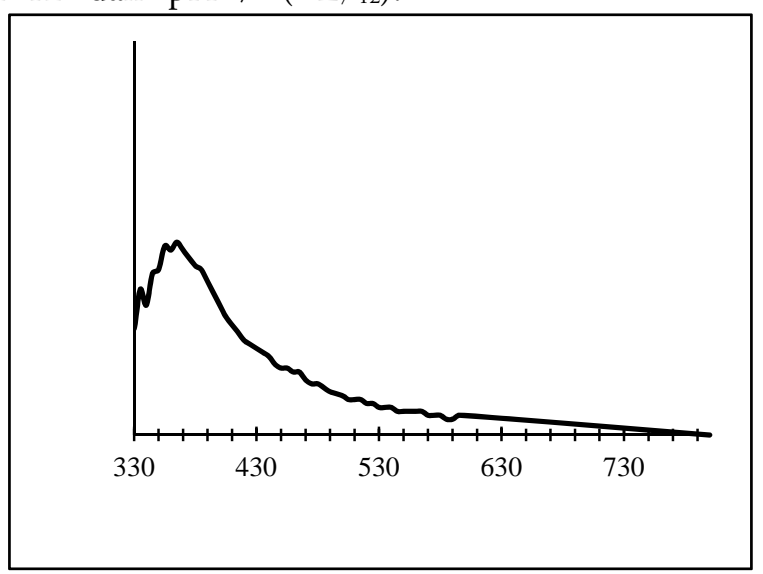

Gambar 5. Spektrum $\Delta \mathrm{E}_{7-12}$ asam humat

Hasil studi pada lignin yang menunjukkan bahwa pita serapan pada panjang gelombag rentang 300 sampai $400 \mathrm{~nm}$ pada spektrum $\Delta \mathrm{E}_{7-12}$ merupakan karakteristik untuk fenol yang mempunyai gugus karbonil terkomjugasi atau ikatan rangkap terkonjugasi sebagai rantai samping dan unit struktur bifenil atau stilben dengan gugus hidroksil bebas (Terashima, 1982). Hasil spektrum $\Delta \mathrm{E}_{7-12}$ asam humat dari kompos tandan kosong sawit yang dihasilkan dari ekstraksi pada Gambar 5 . menunjukkan sebuah puncak pada 360 dan $370 \mathrm{~nm}$ yang memenuhi kriteria studi pada lignin. Hasil spektrun $\Delta \mathrm{E}_{7-12}$ dengan puncak pada 360 dan 370 menunjukkan adanya karakteristik fenol yang mempunyai gugus karbonil terkonjugasi pada asam humat dari kompos tandan kosong sawit.

Berdasarkan analisis yang telah dilakukan dapat disimpulkan bahwa asam humat dari kompos tandan kosong sawit adalah benar asam humat. Hal ini dibuktikan dengan karakteristik yang menunjukkan ciri khas dari asam humat. Asam humat yang dihasilkan bawarna coklat kehitaman, tidak larut didalam larutan basa, memiliki gugus fungsi $-\mathrm{OH}$ fenolik, ragang $\mathrm{C}=\mathrm{O}$, deformasi $\mathrm{O}-\mathrm{H}$ dari-COOH, memiliki struktur yang relatif alifatik dengan gugus fungsi yang banyak, dan memiliki karakteristik fenol yang mempunyai gugus karbonil terkonjugasi.

\section{Karakterisasi Gugus Fungsional Asam Humat}

Penentuan gugus fungsional asam humat secara kuantitatif dilakukan dengan mencari nilai keasaman total, gugus karboksilat, dan gugus - $\mathrm{OH}$ fenolat, yang dilakukan dengan metode titrasi potensiometri. Adapun hasil analisis kandungan gugus fungsional asam humat kompos tandan kosong sawit tersaji pada Tabel 2 .

Tabel 2. Kandungan Gugus Fungsional Asam Humat Kompos Tandan Kosong Sawit

\begin{tabular}{cccc}
\hline No & Gugus fungsional & Kandungan hasil penelitian $(\mathrm{cmol} / \mathrm{kg})$ & Penelitian Schnitzer $(\mathrm{cmol} / \mathrm{kg})$ \\
\hline 1. & Keasaman total & 7.400 & $570-890$ \\
2. & Karboksilat & 520 & $150-570$ \\
3. & OH Fenolat & 6.880 & $270-350$ \\
\hline
\end{tabular}


Berdasarkan Tabel 2 dihasilkan keasaman total asam humat hasil penelitiaan sebesar 7.400 $\mathrm{cmol} / \mathrm{kg}$. Keasaman total atau kapasitas tukar asam humat terjadi akibat adanya proton yang dapat terdisosiasi atau pelepasan ion-ion $\mathrm{H}^{+}$pada gugusgugus karboksilat dan gugus hidroksil fenolat. Keasaman total asam humat dapat menunjukkan konsentrasi asam yang terdapat didalam senyawa asam humat. Berdasarkan hasil penelitian, keasaman total yang dihasilkan menunjukan konsentrasi asam yang cukup tinggi didalam senyawa asam humat. Penetapan kandungan keasaman total asam humat pada penelitian ini manggunakan metode barium hidroksida, dimana dilakukan dengan pendekatan titrasi potensiometri dan didasarkan pada pelepasan ion $\mathrm{H}^{+}$dari gugusgugus fungsional asam humat yang bersifat asam. Pada penelitiaan ini asam humat kompos tandan kosong sawit direaksikan dengan barium hidrosida secara berlebih, kemudian sisa barium hidroksida yang tidak bereaksi dengan asam humat dititrasi secara potensiometri dengan larutan standar asam ( $\mathrm{HCl} \mathrm{0,5} \mathrm{M)} \mathrm{hingga} \mathrm{pH} \mathrm{8,4} \mathrm{(Stevenson,} \mathrm{1994)}$

Hasil penelitiaan selanjutnya yaitu penentuan gugus karboksilat. Penentuan gugus karboksilat dilakukan dengan menggunakan metode Ba-asetat, dimana sampel asam humat direaksikan dengan $\mathrm{Ba}$-asetat, kemudian asam asetat yang dibebaskan dititrasi dengan larutan standar basa $\mathrm{NaOH} \mathrm{0,1} \mathrm{M} \mathrm{hingga} \mathrm{pH}$ 9,8 (Stevenson, 1994). Berdasarkan Tabel 2. dihasilkan gugus karboksilat asam humat hasil penelitiaan sebesar $520 \mathrm{cmol} / \mathrm{kg}$. Selain penentuan gugus fungsional asam humat seperti penentuan keasaman total dan gugus karboksilat, penuntuan gugus $-\mathrm{OH}$ fenolat juga dilakukan. Gugus $-\mathrm{OH}$ fenolat merupakan selisih nilai antara nilai keasaman total dan nilai gugus karboksilat. Berdasarkan hasil penelitian pada Tabel 2 didapatkan nilai gugus - $\mathrm{OH}$ fenolat sebesar $6.880 \mathrm{cmol} / \mathrm{kg}$.

Berdasarkan Tabel 2, kandungan keasaman total dan $-\mathrm{OH}$ fenolat lebih besar dari pada penelitiaan Schnitzer (1982). Perbedaan nilai antara hasil penelitian dan referensi adalah karena pada penelitian ini asam humat diperoleh dari kompos tandan kosong sawit yang banyak mengandung lignin. Lignin merupakan polimer aromatik dari gugus fenil propan, yang terdiri dari monomermonomer 4-hidroksi-3-metoksi fenil propana, 3-5dimetoksi-4-hidroksi fenil propana dan 4-Hidroksi fenil propana (Tan, 2014). Berdasarkan monomermonemor gugus fenil propan, monumer lignin banyak mengandung gugus - $\mathrm{OH}$ fenolat, dimana gugus ini merupakan penghasil ion $\mathrm{H}^{+}$terbesar (selain $-\mathrm{OH}$ alkohol, $-\mathrm{COOH}$ karboksilat) dari asam humat hasil penelitiaan ini (nilai keasaman total besar).

Asam humat yang dihasilkan dari kompos tandan kosong sawit menghasilkan nilai kandungan gugus fungsional yang reatif tinggi daripda asam humat yang dihasilkan dari tanah gambut, tinja kuda dan asam humat dari kompos kotoran sapi. Hal ini bisa saja disebabkan oleh bahan utama yang digunakan, karena bahan utama dari kompos tandan kosong sawit yaitu banyak mengandung lignin.

\section{Kesimpulan}

Kompos tandan kosong sawit dapat menghasilkan asam humat, dimana asam humat yang dihasilkan berbentuk padatan bewarna cokelat kehitaman dengan nilai randemen sebesar $4,8 \%$. Hasil spektrum FTIR dan Uv-Vis menunjukkan serapan yang khas untuk asam humat yaitu pada bilangan gelombang untuk gugus- gugus $-\mathrm{OH}$, regang $\mathrm{C}=\mathrm{O}$, regang $\mathrm{C}-\mathrm{O}$, $-\mathrm{OH}$ fenolik, dan deformasi $-\mathrm{OH}$ dari $-\mathrm{COOH}$ dan struktur asam humat yang relatif alifatik dengan gugus fungsi yang banyak dan memiliki karakteristik fenol dengan gugus karbonil terkonjugasi. Asam humat dari kompos tandan kosong sawit mengandung total keasaman sebesar $7.400 \mathrm{cmol} / \mathrm{kg}$, gugus karboksilat sebesar $520 \mathrm{cmol} / \mathrm{kg}$, dan nilai kandungan gugus $\mathrm{OH}$ fenolat sebesar $6.880 \mathrm{cmol} / \mathrm{kg}$.

\section{Ucapan Terima Kasih}

Penulis mengucapkan terima kasih kepada kepala laboran laboratorium kimia FMIPA Untan dan semua pihak yang telah membantu dalam pelaksanaan penelitiaan ini.

\section{Referensi}

Agus, F., \& Subiksa, I. G. M. (2008). Lahan gambut: Potensi untuk pertanian dan aspek lingkungan. Bogor: Balai Penelitian Tanah dan World Agroforestry Centre (ICRAF).

Babarabie, M., Atoosa, A., Sara, H., Mohammad, A. B., \& Maryam, D. (2016). The effect of sulfur containing humic acid on yield and nutrient uptake in olive fruit. Open Jurnal of Ecology, 7(4), 279-288.

Basuki, R., Bambang, R., \& Sri, J. S. (2017). Ekstraksi adsorben ramah lingkungan dari matriks biologi: asam humat tinja kuda $(\mathrm{AH}-$ TK). Jurnal Chempublish, 2(1),16-17.

Gusrizal, \& Afghani, J. (2005). Spektrum ultraungu/sinar tampak asam fulvat yang diisolasi dari air gambut. Jurnal Natur Indonesia, 7(2), 84-87.

Gaffney, J. S., Marley, N. A., \& Clark, S. B. (1996). Humic and fulvic acid: Isolation, structure and environmental role. Washington D. C.: American Chemical Society.

Hambali, E. S., Mujdalipah, A. H., Tambunan, A.W., Pattiwiri, \& Hendroko, R. (2007). Teknologi bioenergi. Jakarta: Agromedia Pustaka.

Isroi. (2008). Kompos. Bogor: Balai Penelitian Bioteknologi Perkebunan Indonesia.

Khaled, H., \& Fawy, H. A. (2011). Effect of different levels of humic acids on the nutrient 
content, plant growth, and soil properties under conditions of salinity. Soil \& Water Res, 6(1), 21-29.

Narsito., Risfidian, M., Nurlisa, H. \& Sri, J. S. (2008). Karakterisasi asam humat dari gambut indralaya, ogan ilir sumatera selatan. Jurnal Penelitiaan Sains, 11(1), 411-420

Rahmawati, A. (2011). Isolasi dan karakterisasi asam humat dari tanah gambut. Jurnal Phenomenon, 2(1), 128-129.

Samat, \& Lesbani, A. (2012), Studi interaksi seng(II) pada asam humat muara kuang serta aplikasinya terhadap limbah industri pelapisan seng. Jurnal Penelitian Sains, 15(1), 22-23.

Senesi, N., \& Loffredo, E. (1998). The chemistry of soil organic matter, spark, D. L. (ed). Soil Physical Chemistry. $2^{\text {nd }}$ ed. Boca Raton: CRC Press.

Standar Nasional Indonesia Nomor 19-7030-2004. Jakarta: Standar Kualitas Kompos.

Stevenson, F. J. (1982). Humus chemistry: Genesis, composition, and reactions. New York: A Wiley Interscience Publ John Wiley \& Sons.

Stevenson, F. J. (1994). Humus chemistry: Genesis, composition, and reaction. 2 nd ed. New York: John Wiley and Sons Inc.

Schnitzer, M. (1982). Organic matter characterisation in methods of soil analysis, chemical and microbiological properties, part 2, Hadison Asa, monograph No. 9, 2nd Edition, 581-594.
Sutanto, R. (2002) Penerapan pertanian organik. Jakarta: PT. Kanisius.

Tan, K. H. (2014). Humic matter in soil and the environment. New York: Taylor \& Francis Group.

Terashima, N. (1982). Physical properties, Nakano, J (ed), chemistry of lignin. Tokyo: Uni Publishing Co.

Tsutsuki, K., \& Kuwatsuka, S. (1979). Chemical studies on soil humic acids, VII, pHdependent nature of the ultraviolet and visible absorption spectra of humic acids. Soil Science and Plant Nutrition, 25, 373-384.

Warsito, J., Sabang, S. M. \& Mustapa, K. (2016). Pembuatan pupuk organik dari limbah tandan kosong kelapa sawit, Jurnal Akademika Kimia, 5(1), 8-15.

Wershaw, R. L. (2004). Evaluation of conceptual models of natural organic matter (humus) from a consideration of the chemical and biochemical processes of humification, scientific investigations report 2004-5121U.S. Department of the Interior and U.S, Geological Survey Denver.

Wijaya, H., \& Suwardi. (2013). Peningkatan Produksi tanaman pangan dengan bahan aktif asam humat dengan zeolit sebagai pembawa. Jurnal Ilmu Pertanian Indonesia, 18(2), 79-82.

Watanabe, A., \& Kuwatsuka, S. (1991). Triangular diagram for humus composition in various types of soils. Soil Science and Plant Nutrition, 37, 167-170. 